\title{
Exploring 'Aboriginal' sites in Sydney: a shifting politics of place?
}

\author{
Melinda Hinkson
}

In 2000 I was employed by the Australian Institute of Aboriginal and Torres Strait Islander Studies (AIATSIS) to write a monograph about Aboriginal sites in Sydney. The brief for the project was very broad: what might constitute 'a site' was not pre-determined, nor was any other aspect of the content, although it was stipulated that the book be developed in consultation with Sydney's peak Aboriginal organisations, most particularly land councils. The research was undertaken collaboratively with Alana Harris, renowned Wiradjuri photographer, and the outcome was Aboriginal Sydney: a guide to important places of the past and present, published by Aboriginal Studies Press in $2001 .^{1}$ The book is a guide to fifty places in the greater Sydney region, an area bordered by $\mathrm{Ku}$ ring-gai Chase National Park in the north, Cranebrook and Greendale in the west, and Kurnell and Botany Bay in the south. It is intended for a very broad audience, and designed to be used as a straightforward guide book as well as a selective and short social history of Sydney.

The impetus for writing this essay was a keenness to tease out some of the issues that arose in the context of the research that were not canvassed in Aboriginal Sydney. When I first travelled to Sydney I was struck by what appeared to be a shifting phenomenon. On the one hand, as has been widely observed, some Aboriginal sites were relatively easy to find, specifically those sites often described as 'pre-contact' such as rock engravings, shell middens, occupation shelters. A good number of these are signposted. However sites of colonial and more recent times - the places that mark encounters between Aboriginal and non-Aboriginal people - were much more difficult to locate. These 'contact' and 'post-contact' sites were largely invisible; many receiving little if any public recognition. In this sense the status of Sydney's Aboriginal places appeared to directly mirror the experience historically common for Aboriginal people living in urban areas - the denial of their existence as Aboriginal. Yet on second glance this interpretation was not as clear-cut as it seemed at first. Undertaking this research in the months leading up to the Sydney Olympics, and in the final year of the Council for Aboriginal Reconciliation's ten year term, Alana and I found ourselves in the midst of what appeared to be a explosion of interest in Sydney's Aboriginal history. This interest

1. Part of the inspiration for this project was provided by Meyer Eidelson's (1997) book, The Melbourne Dreaming that proved to be a popular title for Aboriginal Studies Press. 
was reflected, among other things, in the number of researchers we encountered who were undertaking similar projects to our own - people working for municipal councils who had commissioned Aboriginal histories of their local area, ${ }^{2}$ for the organisers of Sydney's Olympic Games, for Lonely Planet's Guide to Aboriginal Australia and the Torres Strait Islands, for the National Parks and Wildlife Service, and for local land councils. This apparent interest in Sydney's Aboriginal history was making its impact felt keenly in the city's urban landscape, as a series of new sites and new approaches to the interpretation of sites were being implemented. In this process, Sydney seemed to be gaining a past that had until recently been denied - it was becoming a city with an Aboriginal history. ${ }^{3}$ But what exactly was being produced in this process? What kinds of representations of Aboriginality were emerging? And, in what ways, if at all, could it be said that these representations differed from those identified and analysed in relation to Sydney's Aboriginal sites in the past?

\section{Debunking some binary oppositions}

The wider context of this essay - the relationship between the production of certain forms of 'Aboriginality' and the reification of Aboriginal places as meaningful in particular kinds of ways - has of course been extensively discussed by a number of historians, archaeologists, anthropologists, and others. ${ }^{4}$ As Attwood has argued, the 'ever present image' of 'the Aborigine' for much of the past 200 years has been one firmly located outside time - historically in Australia Aborigines have been 'consigned to the past, but not to history'. ${ }^{5}$ A key signifying label in this process is 'traditional Aboriginal culture', firmly fixing all 'authentic' forms of Aboriginality within an imagined pre-colonial moment and viewing all forms that diverge from it, and the living Aboriginal people associated with those forms, as diminished and impoverished versions. Wolfe's term 'repressive authenticity' captures well this process, in which living Aboriginal people and the challenges they pose to settler colonial society have been cut loose from the dominant representations of Aboriginality that are prevalent, and indeed traded, within those same societies. ${ }^{6}$ Images of exotic and ancient cultural richness are extremely useful in the workings of nation-states; unresolved political contests are not. Frequently, early anthropological accounts have been pointed to as the prime carriers of this process, ${ }^{7}$ however one does not have to look far for examples that demonstrate the continuing pervasiveness and cogency of repressive authenticity in the present. The widespread use of images of 'traditional Aboriginal culture' in the tourism trade is one obvious example. The perpetuation of such binary frameworks as traditional/modern within which to classify Aboriginal cultures and lives is integral to this process. At a more abstract level, writers have argued that the mobilisation of images of radical alterity or 'otherness' has been central to the construction of nation-states and their maintenance of stability. ${ }^{8}$

See for example City of Sydney 2001.

Byrne 1996.

4. See for example Attwood 1989, 1996a, 1996b; Byrne 1996; Colley \& Bickford 1996; McBryde 1986, 1989.

5. Attwood 1996: xii.

6. Wolfe 1999

7. See for example Attwood 1996; Hiatt 1996; Wolfe 1999; Stocking 1996; Povinelli 2002. 
Denis Byrne has tracked the ways in which the unhinging of a primitivist or 'traditional' Aboriginality from living Aboriginal people has been carried over into the discipline of archaeology and heritage practice, noting that ' $[\mathrm{t}] \mathrm{hrough}$ a process of monumentalisation, archaeology has helped conceptualise "genuine" indigenous culture not so much as entirely swept away but as contained or confined in the form of archaeological sites ... as the Aborigines faded (ie changed) the sites stood for them' ${ }^{9}$ Byrne's work provides a compelling interpretive framework with which to approach an exploration of Sydney's Aboriginal sites and to consider any changes that might be occurring in that physical and representational landscape.

Rock engravings, rock art sites, sandstone shelters, and scarred trees of pre-colonial Aboriginal society and the early colonial era are abundant in Sydney, and extensively documented. ${ }^{10} \mathrm{~A}$ disproportionate attention to the pre-colonial era is reflected in the Aboriginal Sites Register maintained by NSW NPWS, which holds records for some 30,000 sites, only a few hundred of which belong to the post-1788 period. Similarly, of the 17,500 sites listed on the NSW Heritage Register (all of which date from 1788) only seven have been placed there for their value to Aboriginal people. ${ }^{11}$ As Byrne has observed, such registers have come to stand for 'pure products' sites 'which speak of a pure, authentic and, most importantly, always former Aboriginal presence'. ${ }^{12}$ In averting our gaze from those sites that were produced in encounters between Aborigines and Europeans, we shield ourselves from having to confront the reality of our involvement in the colonial process. ${ }^{13}$ This lack of recognition accorded to sites of colonial and more recent significance reflects ongoing contests over the writing of Australia's history, ${ }^{14}$ and more specifically, unresolved conflicts between urbanbased Aboriginal people and state and federal governments over claims to land and compensation for historic dispossession. ${ }^{15}$ While these conflicts are very much alive and well in the present period, as noted above, a visit to some of the 'Aboriginal' places of Sydney suggests that the stark delimitation between the recognition of Australia's ancient past as opposed to that which dates from 1788 is in some sense beginning to fray at the edges.

In what follows I briefly explore a selection of six sites that have emerged in crosscultural interactions in the Sydney region post-1788, and consider how these places and the events with which they are associated are presented for public consumption in the present period. Many of these sites will be familiar to readers of Aboriginal History, while recent developments discussed in relation to some sites may not be.

8. Byrne 1996: 95; Wolfe 1999; Povinelli 2002

9. Byrne 1996: 87. See also Nugent 2002.

10. McCarthy 1970; Attenbrow 1991; McDonald 1994; Colley \& Bickford 1996; Stanbury \& Clegg 1996.

11. Nugent 2002.

12. Byrne 1996.

13. Attwood 1996; Byrne 1996.

14. Recent debate over the historical accounting of frontier violence is one example of such contest. See Attwood and Foster 2002; Windshuttle 2002.

15. Goodall 1988, 1996. 


\section{Site 1: Bennelong Point}

The Sydney Opera House sits astride one of the most symbolically important places of Australia's colonial past. Well before the Opera House was erected on this site, this point of land was a significant meeting place for local Aboriginal people. Two years after the British arrived, Governor Arthur Philip had a small brick hut erected on the site for his close friend, Bennelong, a Wangal man, and the most celebrated cross-cultural mediator of the early colonial period. Bennelong's story reflects much about early colonial encounters in Australia. In their desperation to foster improved communication with local Aboriginal people in the first years after their arrival, in two separate incidents the British kidnapped three Aboriginal men in the hope that they could be trained to act as go-betweens. The first man to be taken was Arabanoo, who died in the first epidemic of smallpox that decimated Sydney's Aboriginal communities in 1789. ${ }^{16}$ Six months after Arabanoo's death, Bennelong was taken along with another Aboriginal man, Colebee, in what William Bradley described as 'the most unpleasant service' he was ever 'ordered to execute'. ${ }^{17}$ Bennelong was clearly interested and engaged by the activity of the colony and when Colebee escaped Bennelong chose to stay on. He developed close relationships with a number of officers, especially Governor Phillip, relationships he maintained after fleeing the settlement, some seven months after his capture. When Phillip left Sydney to return to London in 1793, he took Bennelong with him. They were accompanied by another Aboriginal man, Yemmurrawannie, who was later to become the first Aborigine to die and be buried in London. Bennelong in turn developed a taste for fine clothes and wine. He returned to Sydney in 1795, but never readjusted. He died in 1813, a lonely alcoholic with a broken spirit, and was buried in the grounds of James Squire's property at Kissing Point. ${ }^{18}$ Historical photographs uncovered by Isabel McBryde ${ }^{19}$ suggest that Bennelong's grave may be located in the vicinity of present-day Bennelong Park in Putney.

After Bennelong's death his brick hut at Bennelong Point was demolished. However, this area continued to be an important meeting place for Aboriginal people, as indeed it was prior to its association with Bennelong. Throughout the 1800s Aboriginal people continued to camp in semi-permanent fashion at Circular Quay, until the authorities forced the closure of their camps in the 1880s. The site's symbolic significance to Aboriginal people in the present period was demonstrated at the 1999 memorial service for renowned Aboriginal activist Charles Perkins, with the procession of mourners walking through central Sydney to Bennelong Point.

Although remembered in the place name Bennelong Point, there is no signage in the area where the Opera House now stands to tell the thousands of visitors that flock to this area every week anything of its historic significance. However, in the adjacent Botanic Gardens, horticulturalist and Aboriginal Education Officer John Lennis has recently planted a new display, Cadi Jam Ora, which explores the Aboriginal significance of this area. More particularly, the display deals with the first three years of

16. Tench 1961: 150-1.

17. Bradley 1969: 181-2.

18. Smith 2001

19. McBryde 1989. 


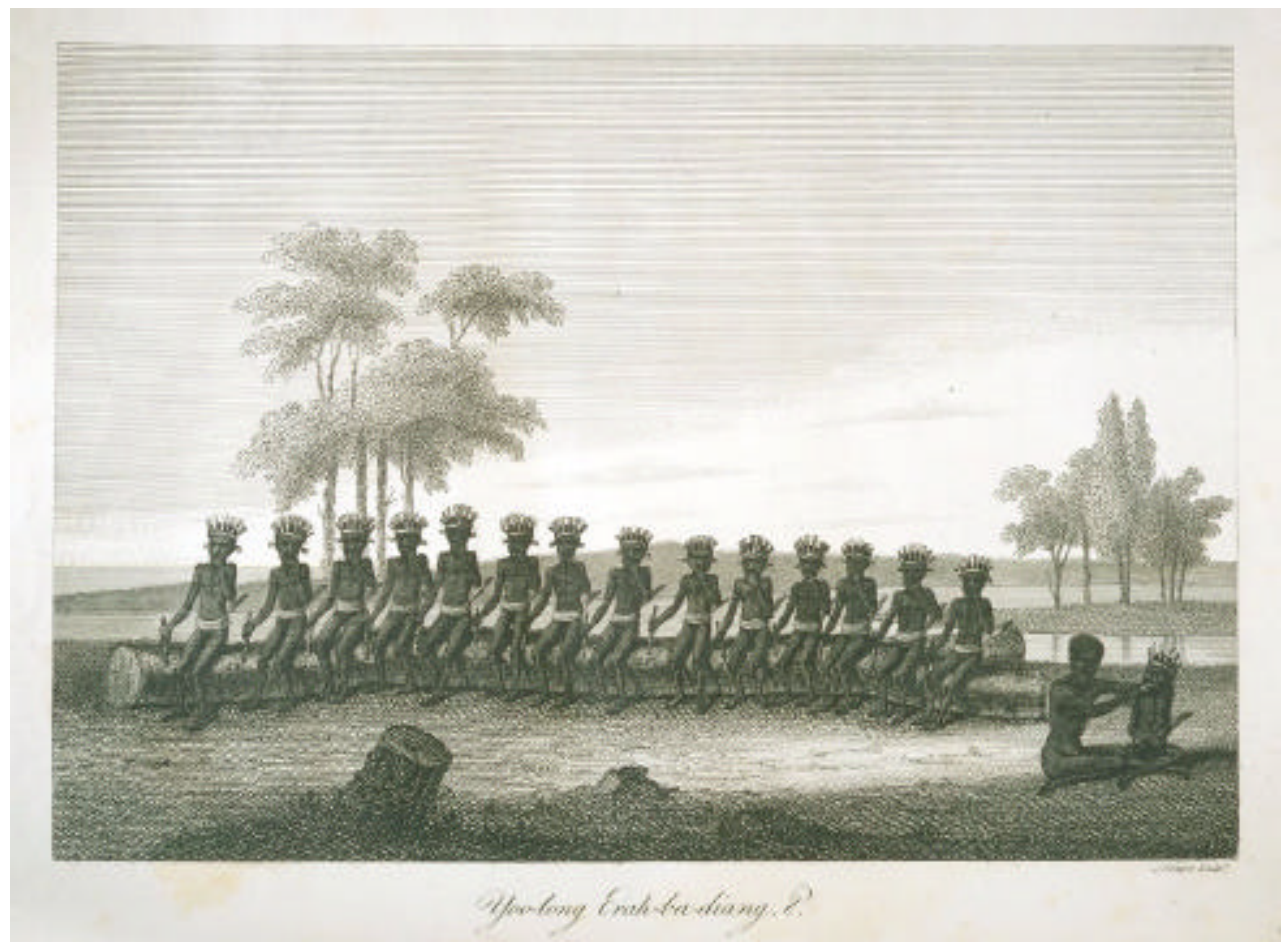

Figure 1: Yoo-lang erah-ba-diang, 1798, drawing by James Neagle, in Collins 1975 [1798]. Courtesy of the National Library of Australia.

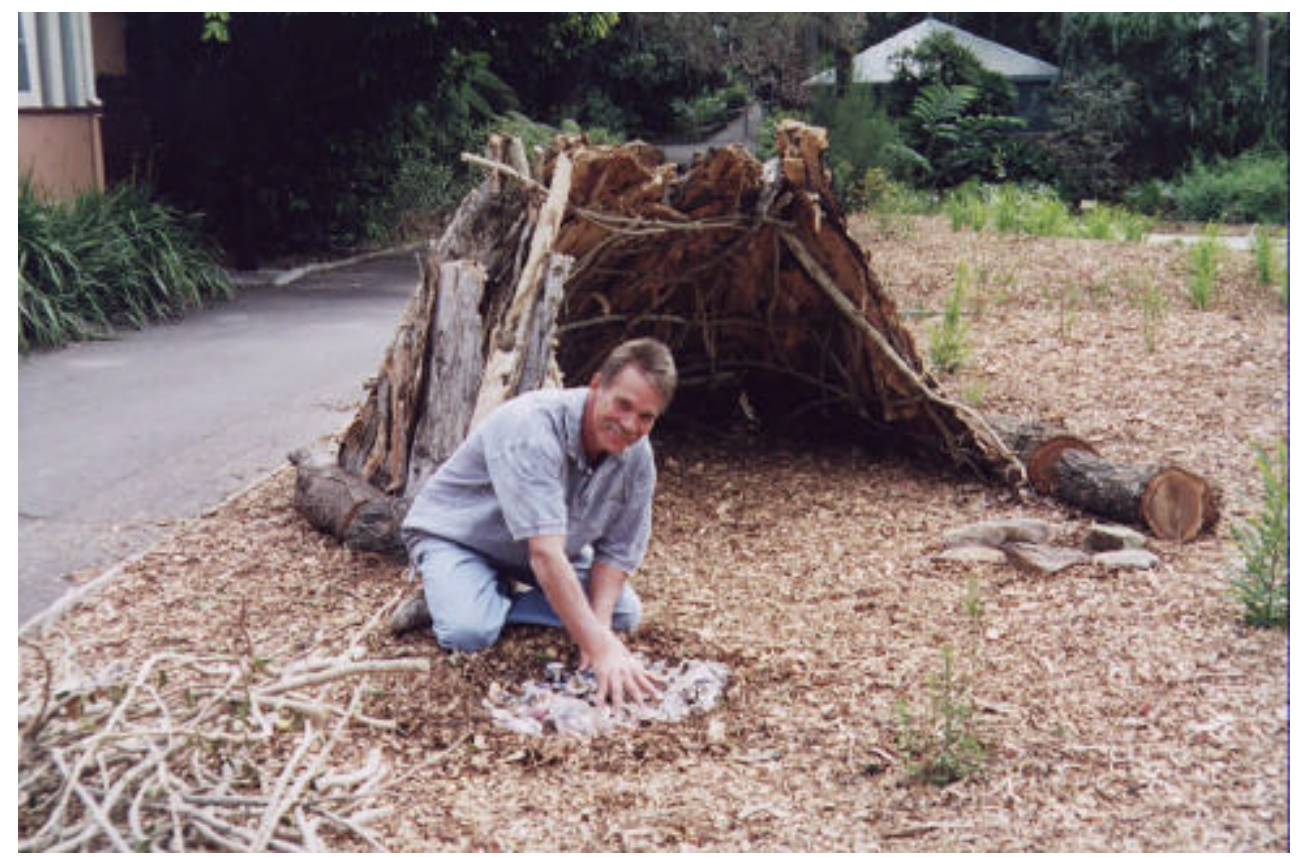

Figure 2: Aboriginal Education Officer John Lennis with his Cadi Jam Ora garden display at the Royal Botanic Gardens. Courtesy of the Royal Botanic Gardens. 
interaction between Aboriginal and non-Aboriginal people, through their different use of plant species and attitudes to the environment.

It is believed that a bora ring or ceremonial ground once occupied land that came to be occupied by the gardens. David Collins observed an initiation ceremony on this site in January 1795 - seven years after the British had arrived. Collins' sketches and descriptions of the events he recorded as Yoo-lahng Erah-ba-diahng, provided inspiration for Neagle's famous series of drawings by the same name. ${ }^{20}$

\section{Site 2: Old Government House}

Not long after the British had established the colony at Sydney Cove, they faced a looming crisis. Attempts to cultivate land at Farm Cove had failed. Food supplies were dwindling and an urgent situation was arising: by October 1788 there was simply not enough to feed the colony. Surveying expeditions had identified country further inland that was deemed more suitable for opening up to agricultural development. Phillip directed that a second settlement be established at a place he named Rose Hill. He later took the unprecedented step of dropping Rose Hill in favour of the name used by local Aboriginal people, Parramatta, anglicised from Burramatta. ${ }^{21}$ The first fleet diarists provide no explanation for this act, but it reminds us of Philip's early attempts at conciliation. $^{22}$

A Government House was built in what today is Parramatta Park. The first section of this house, Phillip's hut, was built in 1790, making this the oldest public building in Australia. Old Government House is a major tourist attraction and the National Trust operates guided tours of the house on a daily basis. Such tours foster an appreciation of the courage and fortitude of the Governors and their families who lived in the house, of the hardship of life in the colony, and of the volatile nature of a society built on the back of convict labour. This framing of the house within the terms of colonial heritage is reinforced at present by the content of the small gift shop attached to the house, whose predominant focus is on local history. Given this focus, I was struck by the fact that there was not a single book included that acknowledged that the Parramatta region had an Aboriginal history.

But this framing of Old Government House within an uncontested colonial narrative is beginning to be challenged. In recent years the National Trust has itself made some considerable investment in this process. In 1999 the Trust commissioned a study of the Aboriginal significance of the area. ${ }^{23}$ An Education Officer has been working in conjunction with local Darug Aboriginal people to develop an education program, in the first instance for delivery to school groups. Armed with the knowledge that informs this program, a visit to Parramatta Park and Old Government House becomes a very different experience - drawing visitor's attention to such features as the brickwork of the house, held together with mortar made from ground-down Aboriginal shell middens, that once lay in enormous heaps along the Parramatta River; a number of scarred trees, whose bark was removed by Aboriginal people to make food and water contain-

20. Collins 1975 [1798]: 466

21. Collins 1975 [1798]: 137; Tench 1961: 239; Hunter 1793: 531.

22. Challis and Smith 2000.

23. Kohen, Knight and Smith 1999 


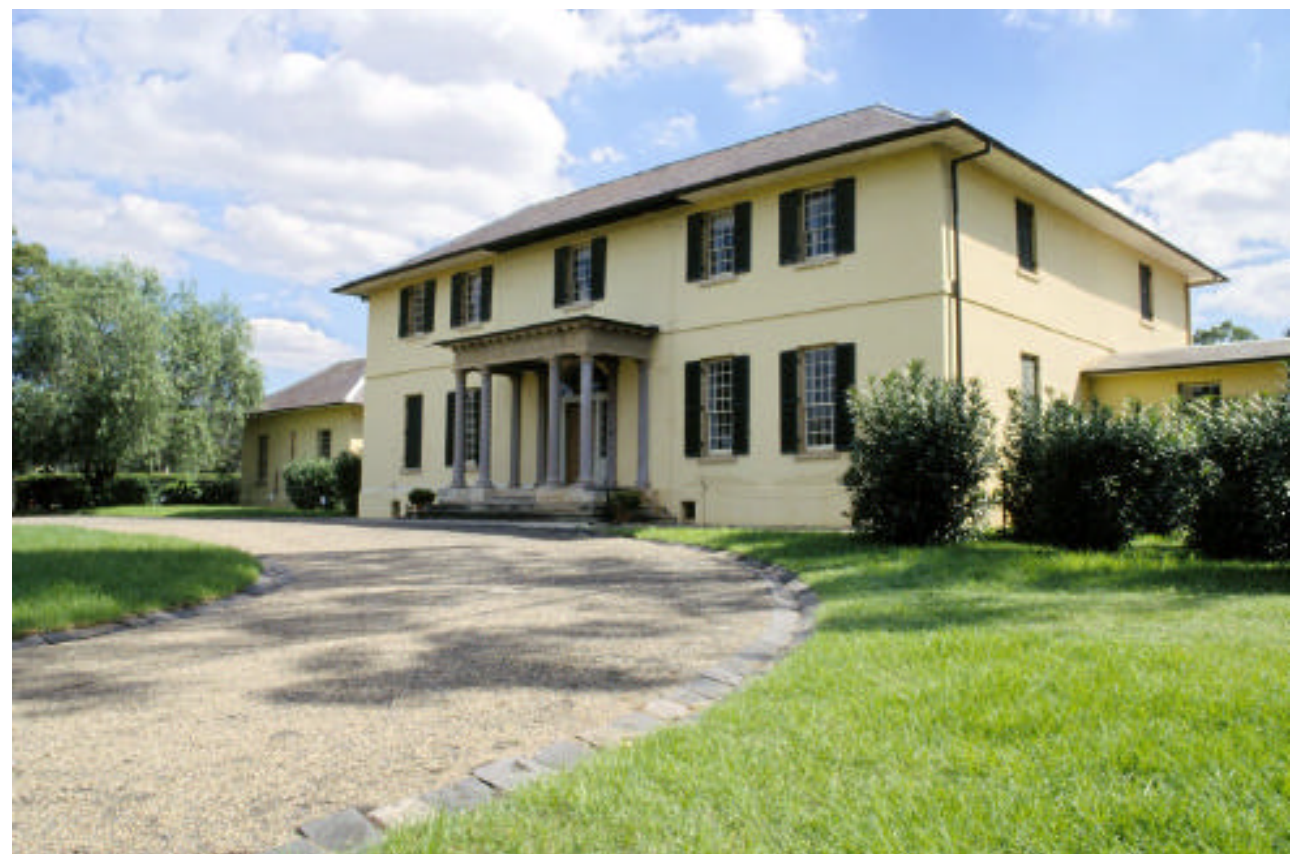

Figure 3: Old Government House, Parramatta Park. Photograph by Alana Harris, courtesy of the Australian Institute of Aboriginal and Torres Strait Islander Studies (AIATSIS).

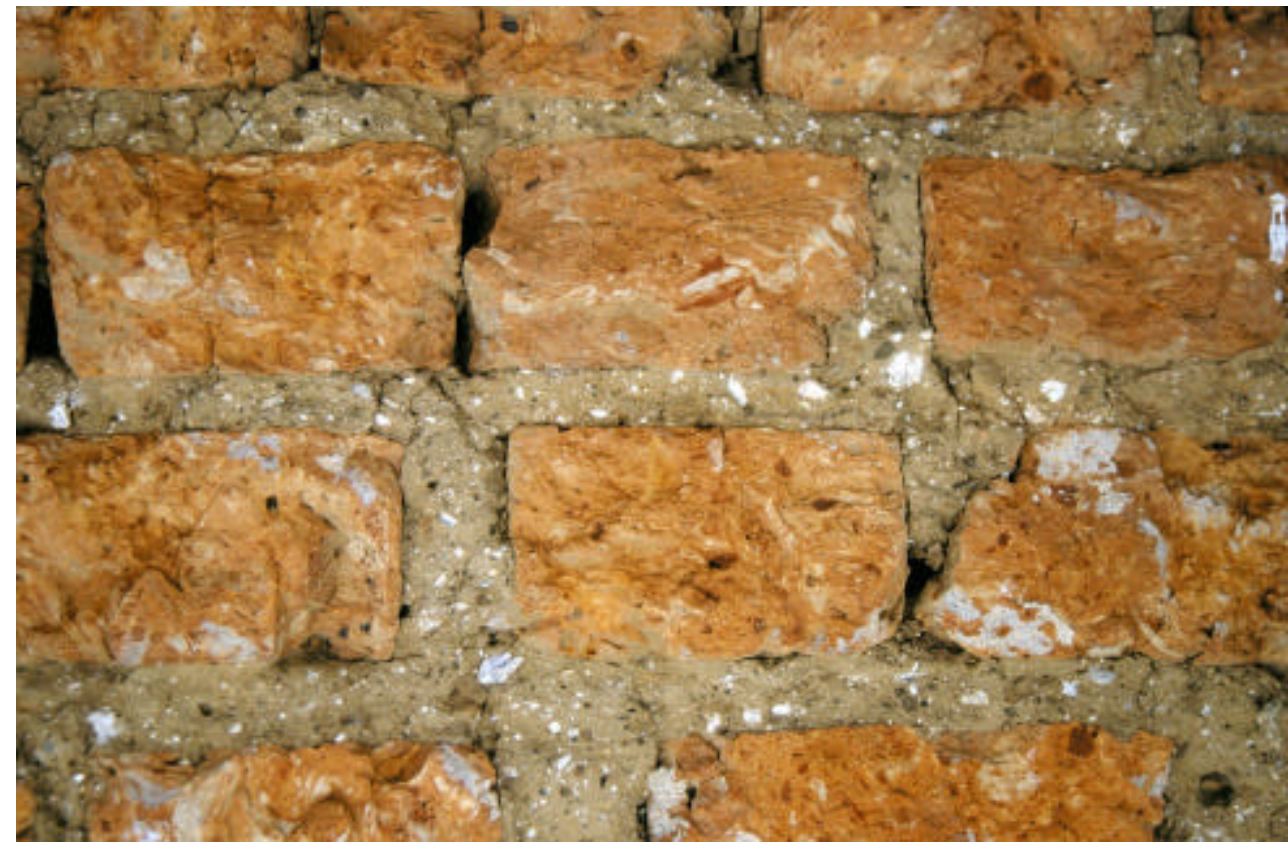

Figure 4: The brickwork of Old Government House. Photograph by Alana Harris, courtesy of AIATSIS. 
ers; and an area behind the house from which significant quantities of stone artefacts were uncovered by archaeologists during their excavation of the area in $1996 .{ }^{24}$ Archaeological evidence, as well as the accounts of First Fleet diarists, suggest that this part of the river once provided a rich source of food for local Aboriginal people. There has also been speculation that an area the rear of the house may have once been the site of a ceremonial ground. ${ }^{25}$ Collins writes of the building of a redoubt or fort prior to the construction of the house, ${ }^{26}$ overlooking the land where the government farm was to be planted, and facing defensively in the direction of the feared Darug and Gandangara tribes of the west and south-west. While this fort was apparently never used in combat, its construction foreshadowed hostilities that would erupt soon after as the colonial frontier expanded into the Aboriginal hunting grounds of the Hawkesbury region. ${ }^{27}$

This perspective on Old Government House is by no means self-evident. There is an absence of interpretive material at the site that might provide insights into its presence. Interpretative displays at the Burramatta Visitor Centre profile some aspects of pre-colonial Aboriginal land use in the vicinity of the park, with material developed in conjunction with local Darug descendants. But interestingly enough the focus of these displays is confined to the pre-colonial period; western Sydney's violent and bloody frontier encounters are not dealt with here. The visitor centre is located at the opposite end of Parramatta Park, some three and a half kilometres from Old Government House and has very limited opening hours. Consequently only a small proportion of visitors to Old Government House would be likely to leave Parramatta with any sense of the area's Aboriginal history. However, the National Trust intends to incorporate aspects of its Aboriginal program into the current house tour, providing visitors with a much broader perspective on the social relations that have inscribed it over time as a significant $_{\text {place. }}{ }^{28}$

\section{Site 3: Native Institution}

Just down the road from Parramatta and Old Government House is one of the most important sites of Aboriginal/European encounters in this region. A pile of rubble in a public reserve in outer suburban Sydney is the site of Governor Lachlan Macquarie's Native Institution, which was establihsed here in 1823, after being moved from its original location in Parramatta. Macquarie's Native Institution enacted what is believed to have been the first institutionalised removal of Aboriginal children from their families in Australian history, in an early colonial experiment to determine the extent to which they could be 'civilised'. ${ }^{29}$

On an annual basis Macquarie held a 'meeting of the tribes and native feast' at Parramatta. He had conceived these events as opportunities for fostering friendly relations with local Aboriginal groups. Blankets were distributed and awards publicly conferred upon those men and women who had 'given proofs of industry and inclination to be civilised' ${ }^{30}$ It was at this annual event that certain Aboriginal leaders of the

24. Attenbrow 1996.

25. Kohen, Knight \& Smith 1999: 17.

26. Collins 1975 [1798]: 37.

27. Collins 1975 [1798]: 348-9; Kohen, Knight \& Smith 1999: 32.

28. National Trust 2000.

29. Brook \& Kohen 1991: 57. 


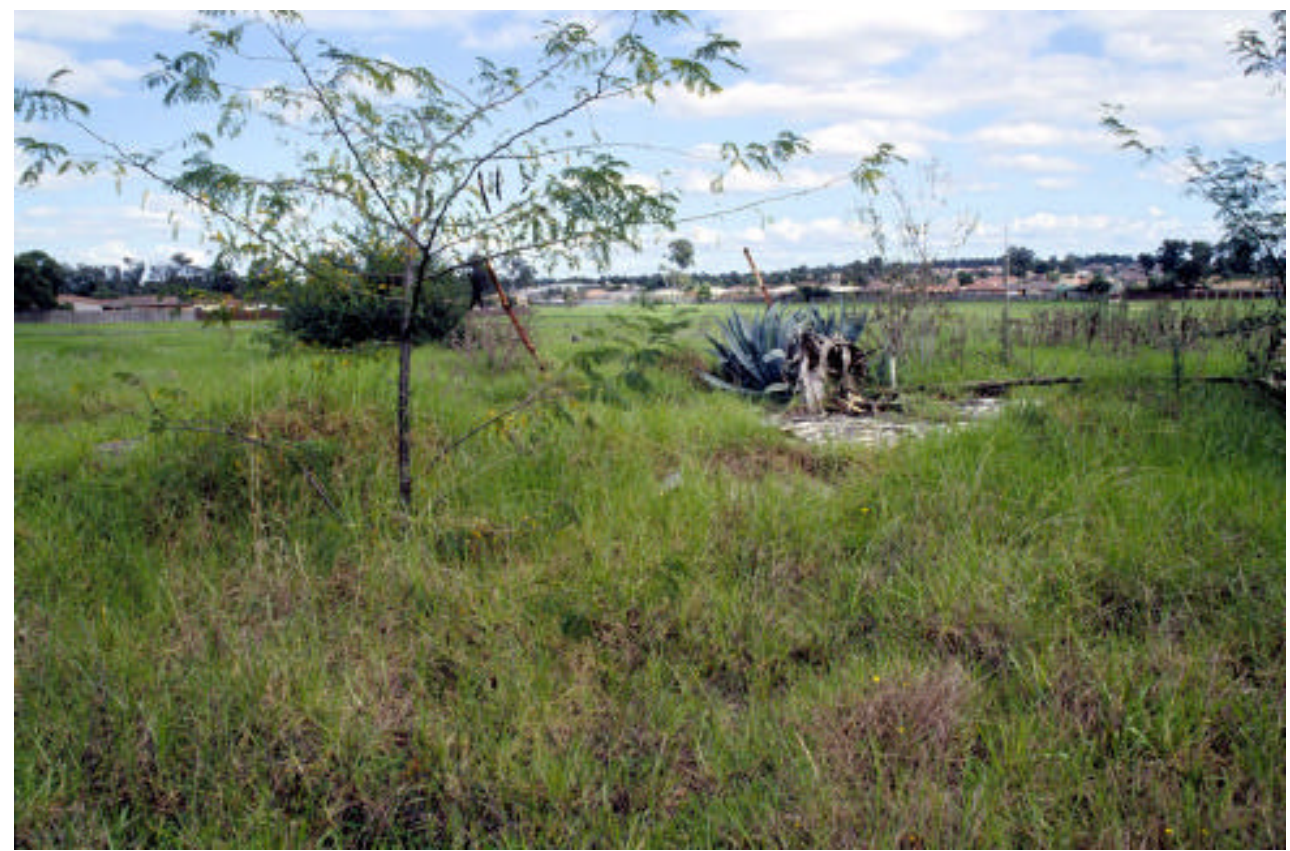

Figure 5: The footings of Governor Macquarie's Native Institution. Photograph by Alana Harris, courtesy of AIATSIS.

region were proclaimed 'chiefs' and presented with gorgets or 'kingplates' ${ }^{31}$ Macquarie also used the occasion of the annual feast to call on Aboriginal parents to give over their children to be lodged in his Native Institution. ${ }^{32}$ A small number of parents were originally persuaded to do so, before they understood the implications of their actions. Once it was clear that they would not be allowed access to their children again, except on one designated day a year, no more children were voluntarily admitted and many of those already lodged in the institution escaped and returned to their families. Subsequent pupils of the Native Institution were taken by force; the next children to be lodged there were captured during punitive expeditions in May and June 1816. ${ }^{33}$ Significantly, it was not only Aboriginal children that were admitted to the institution. The formidable Rev Samuel Marsden, who ran the home for Macquarie for several years, brought a number of Maori children from New Zealand to undergo the same civilising process there.

The native institution experiment was a disaster - in subsequent years a number of children died there, and the institution was finally closed and the land auctioned in $1833 .^{34}$ Little wonder that local authorities are reluctant to memorialise the site's historic significance. The physical state of this site - overgrown by weeds, used from time

\footnotetext{
30. Smith 1992: 84-5.

31. Flynn 1995: 97.

32. Flynn 1995: 95.

33. Kohen, Knight \& Smith 1999: 83.

34. Brook \& Kohen 1991.
} 
to time as a place to illegally dump rubbish, ${ }^{35}$ and encroached upon by suburban development - might be taken to represent the process of selective forgetting in action.

The reserve is significant not only as the site of the Native Institution, but also as a place that has older as well as more recent significance to local Aboriginal people. There is a silcrete quarry nearby, a place where a highly valued material used in the manufacture of tools was once extracted and traded among Aboriginal groups over great distance. The Native Institution site is also located adjacent to what today is the suburb of Blacktown. Blacktown earned its name during Governor Macquarie's time, quite literally as 'the Black Town' - the area in which, ironically, a number of Aboriginal people received grants of land between 1816 and the late 1820s, as reward for their preparedness to work with the British. ${ }^{36}$ Today, Blacktown is home to the largest Aboriginal population in the greater Sydney region. Some of these people are descended from the original Darug occupants of the area. Others have migrated from other parts of Sydney and further afield, forming new kinds of community based on their shared historical experience.

A number of Darug descendants have been campaigning for years to have the Native Institution site preserved and its significance recognised. The site was first surveyed in 1982. ${ }^{37}$ It was listed on the Register of the National Estate in 1992. In 2002 the local Blacktown City Council, Landcom and the NSW Heritage Office commissioned a conservation management plan which at time of writing is at draft stage. Nomination of the site to the state Heritage Register is under way. A range of options for development of the site and promotion of its historic significance have been canvassed in the course of this recent research. ${ }^{38}$

\section{Site 4: Day of Mourning}

In the heart of Sydney, the old Australian Hall building is considered by some to be the birthplace of the Aboriginal civil rights movement in Australia. On Australia Day, 26 January 1938, while the nation celebrated Australia's sesqui-centenary, 100 Aboriginal people and their supporters gathered here to call for an end to what they saw as their callous treatment under the state's Aboriginal protection laws, and for Aboriginal people to be granted full citizenship rights. These meetings were proclaimed as a 'day of mourning'. ${ }^{39}$ The work of those behind these meetings laid the ground upon which subsequent Aboriginal and non-Aboriginal people lobbied, eventually successfully, for the 1967 referendum to be held. The building was threatened with demolition in the mid-1990s and Aboriginal people and their supporters led a protracted struggle, which they finally won, to have a permanent conservation order placed on the building. It was listed on the NSW State Heritage Register in April 1999 and purchased the same year by the Metropolitan Local Aboriginal Land Council, with funds secured through the Indigenous Land Corporation. In 2000 the building underwent refurbishment to restore it to its original condition. For urban-based Aboriginal people there is powerful sym-

\footnotetext{
Colin Gale pers comm.

Brook \& Kohen 1991: 37-44.

Bickford 1981, then by Kohen 1986.

Tracy Ireland pers comm.

Horner 1994: 44.
} 
bolism attached to the Australian Hall. Those associated with the building's reclamation see themselves as continuing a tradition of political activism that has its roots in the activities of the 1930s. ${ }^{40}$

\section{Site 5: Riverside Walk}

In Parramatta, a new site gives a sense of the changing approach to the memorialisation of Sydney's colonial and more recent history discussed above. The Parramatta Riverside Walk is a $750 \mathrm{~m}$ long painted pathway that explores the Aboriginal history of the area, and links the ferry terminal to Parramatta's main street. The artwork was created by local Aboriginal artist Jamie Eastwood. What is particularly interesting in relation to this site is that it not only celebrates the uncontentious aspects of pre-contact Aboriginal society in the Parramatta area, it also confronts the frontier violence associated with invasion. There is no shirking the darkest corners of Australian

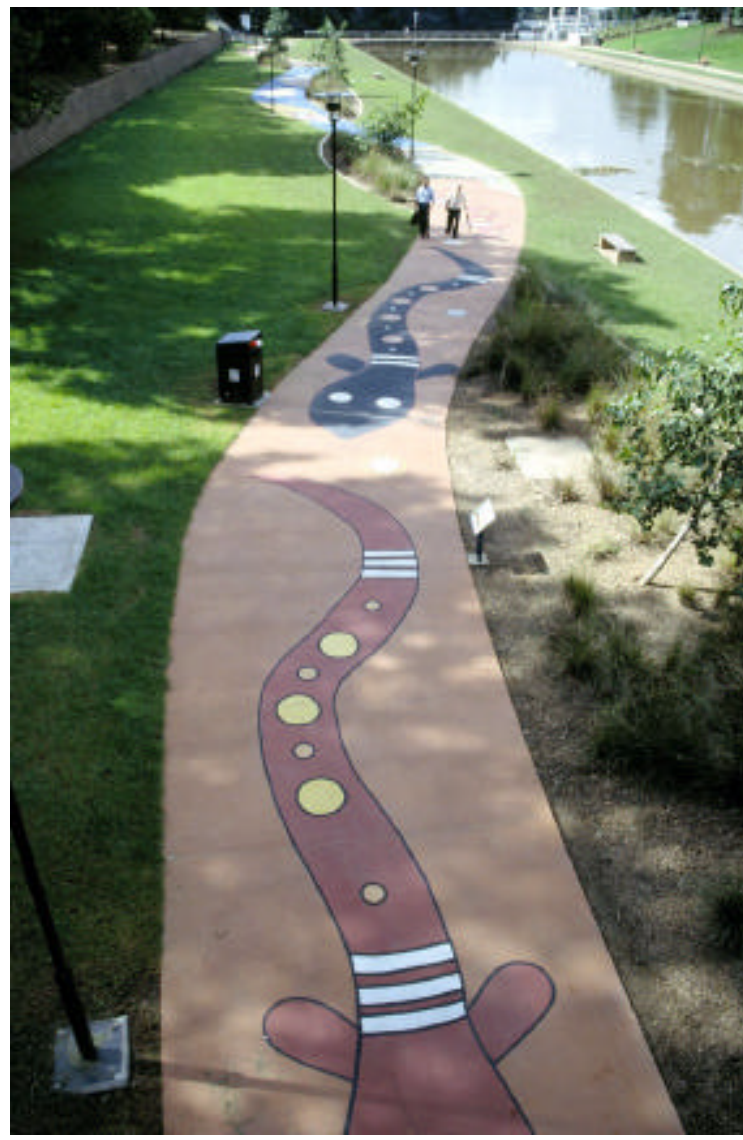

Figure 6: The Parramatta Riverside Walk. Photograph by Alana Harris, courtesy of AIATSIS. history here - the themes of invasion, cross-cultural misunderstand-

ing, massacres, Aboriginal resistance, and the stolen generations are all depicted. Importantly, these are not presented as generalised issues but as specific acts that occurred locally in the Parramatta region. The walk identifies key protagonists such as Governor Macquarie and his Native Institution. The lives of Aboriginal men Baluderri and Pemulwuy and their encounters with the British are also remembered here. Interpretive signage for the walk was developed by Parramatta City Council in consultation with an Aboriginal Advisory Group. The development of the Riverside Walk, as well as a number of other commissioned public artworks in the Parramatta area, ${ }^{41}$ was a local council initiative, and a local response to the reconciliation process. This is made explicit in the themes explored along the walk, as well as in its signage: as one of the interpretive panels states, 'the foreshore landscape works has [sic] embraced an Aboriginal viewpoint'.

\footnotetext{
40. Goodall 1988: 181-97.

41. Hinkson 2001: 128-32.
} 


\section{Site 6: Museum of Sydney}

A final site brings this tour full circle. The Museum of Sydney, on the site of First Government House, stands as a powerful symbol of the contested nature of Australia's history. The Museum's unique interpretation of that history is experienced even before you enter its doors, with Janet Laurence and Fiona Foley's Edge of Trees installation, a collaborative artwork that symbolises the meeting of cultures that is the Museum's central theme. These trees are full of voices speaking the Aboriginal language of Sydney, and layers of material and memory associated with this site are set into their trunks. Inside the Museum a section of earth beneath the floor is exposed, revealing the original footings of the first Government House. This house was a central location for interaction between British officers and local Aboriginal people in the early years of the colony, especially during Phillip's governorship. It was to here that Arabanoo, Bennelong and Colebee were brought after their capture to be trained as go-betweens. Some reports suggest Aboriginal women sought refuge at the house from violent husbands, and medical treatment from Surgeon White. A number of Phillip's close Aboriginal companions such as Arabanoo and Baluderri were buried in his garden. ${ }^{42}$

At the time of our visit to the museum, Gordon Syron's haunting artwork, Invasion 1 - An Aboriginal perspective, was the first image to be viewed as we entered the foyer, making a clear statement about the Museum's preparedness to make explicit its exploration of the contested nature of Australian history. Other exhibits explore Aboriginal people's continuing presence in Sydney - not just through the lens of continuous attachment to place, but through examinations of some of the new kinds of community that have been forged in Sydney over time. Cadigal Place, named for the original inhabitants of the land on which the museum stands, is a space dedicated exclusively to local exhibitions, which are developed in conjunction with a specially constituted advisory group. In amongst the diverse references to Sydney's Aboriginal past are other representations of colonial life. The Museum is most evocative as a place where aspects of the intersecting layers of Australia's history can be explored.

\section{Making visible our shared history}

At the beginning of this article I observed that a common feature of Sydney's Aboriginal places of the post-1788 period has historically been their relative invisibility, but that recent events have seen the beginnings of a shift in this respect. The introduction of a new education program that brings an Aboriginal perspective to a colonial icon such as Old Government House is indicative of such a shift, as is the proliferation of new sites such as the Riverside Walk, the Museum of Sydney, and a range of others not discussed here, including the Muru Mittigar Cultural Centre in Cranebrook, and new dedicated Indigenous display areas such as Bayagul at the Powerhouse Museum. Importantly, not all new sites are the initiatives of local government or cultural institutions. A newly planted 'bush tucker' walk in the grounds of Yarra Bay House at La Perouse, the outcome of a successful local project, reflects one Aboriginal community's interest in participating in this process of a shared and public reinterpretation of history and place.

42. McBryde 1989; Smith 2001. 
What has been the process out of which these new sites and new approaches to interpreting history have emerged? Key moments of an evolving campaign can of course be charted throughout the twentieth century, in particular since the passing of the 1967 referendum. Stanner's identification of the 'great Australian silence' in his 1968 Boyer lectures, ${ }^{43}$ and the sea change in the writing of Australian history that followed were critical moments in this process. As Byrne has noted, the 1970s also marked the beginning of an unrestrained embracing of Aboriginal 'heritage' in Australia. ${ }^{44}$ But this was a heritage 'unhinged' from the concerns and aspirations of living Aboriginal people. Throughout the 1980s urban-based Aboriginal people fought in diverse arenas to gain acceptance of their distinctive identity as Aboriginal people. The 1990s were a momentous decade in Aboriginal Affairs, commencing with the tabling of the final report and recommendations of the Royal Commission into Aboriginal Deaths in Custody in $1991{ }^{45}$ which included the proposal to establish the Council for Aboriginal Reconciliation, subsequently brought to life in a bipartisan Act of Parliament. In 1992 the historic Mabo decision in the High Court overturned the legal fiction of terra nullius. And, in 1997, as the reconciliation movement gathered steam, the Human Rights and Equal Opportunity Commission presented the federal government with its report on the separation of Aboriginal and Torres Strait Islander children from their families. ${ }^{46}$ Reconciliation's 'people's movement' reached its pinnacle in May 2001, with more than 100000 people walking across the Sydney Harbour Bridge in support of the reconciliation process. Similar marches followed in all other capital cities. This people's movement fuelled an explosion of interest in the Aboriginal and colonial histories of Australia, a process grasped particularly enthusiastically at the local community level. Across the country citizens' groups, local municipal councils, and schools have undertaken to revise their official local histories, incorporating previously unrecognised Aboriginal perspectives. As this essay has shown, such activity has been particularly pronounced in large metropolitan centres such as Sydney. The closing ceremony of Sydney's 2000 Olympic Games contributed its own powerful images to this process too, with Australian rock band Midnight Oil belting out their song about land rights, 'Beds are burning', in 'sorry' printed overalls, before an assembled global media.

It would be naive to assume that reconciliation will be the carrier of a complete transformation of Australia's engagement with its colonial past. The process I have described has, of course, been met by a strong and steady counter movement, reflected most prominently since the mid-1990s in the Howard government's attacks on political correctness and the 'black armband' view of history, its amendment of the Native Title Act in 1998, and its refusal to engage in any compassionate way with the claims of the stolen generations. The success of the reconciliation movement in its first stage has lain in its ability to operate as a people's movement, acting independent of and indeed in response to the Howard government's approach to indigenous affairs. While this movement clearly attained significant momentum in recent years, the extent to which

43. Stanner 1969

44. Byrne 1996: 99

45. Commonwealth Government, Royal Commission into Aboriginal Deaths in Custody 1991.

46. National Inquiry into the separation of Aboriginal and Torres Strait Islander children from their families 1997. 
that momentum might be harnessed again in the future is another question altogether. There are a series of related questions that might be posed: To what extent was the reconciliation movement primarily born of a collective emotional outpouring of grief in response to the public airing of the experiences of the stolen generations? Was it a momentary response, or will it hold its resonance over time? Are there other dimensions of Australia's colonial past that might provide a similarly emotionally charged focal point for a broad-based social movement in the future? What are the prospects of the aspirations articulated by a people's movement being given practical effect by political action?

The inscription of places as meaningful in new ways proved to be an integral part of the reconciliation process in the 1990s. The answers to the questions posed here will have implications for the future status of these places. In the worst outcome imaginable these places would fade from view if the people's movement dissipated. In the best possible scenario these sites would continue to gain recognition as anchorage points of shared history, sites where our different and similar experiences of being Australian could be brought together, exchanged, argued over, and finally, accepted.

\section{Acknowledgments}

With thanks to Alana Harris and AIATSIS for permission to reproduce the photographs that appear here. A version of this paper was presented in the Ethnoscapes seminar series at the Centre for Cross-Cultural Research, the Australian National University, March 2002. With thanks to my co-presenter Peter Read, Sylvia Kleinert the series convenor, and those who attended the seminar. I am also grateful to Jon Altman, Aboriginal History's two anonymous referees, and Ingereth Macfarlane for helpful comments on an earlier version of this paper.

\section{References}

Attenbrow, V 1991, 'Port Jackson archaeological project: a study of the prehistory of the Port Jackson catchment, New South Wales, Stage 1', Australian Aboriginal Studies, 2: 40-55.

Attenbrow, V 1996, 'Parramatta Park Plan of Management and Interpretation Program. Aboriginal Sites, Stage Two', report to Parramatta Park Trust, Australian Museum Business Services, East Sydney.

Attwood, B 1989, The making of the Aborigines, Allen \& Unwin, St Leonards.

Attwood, B 1996, 'The past as future: Aborigines, Australia and the (dis)course of history' in Attwood, B (ed) In the age of Mabo: history, Aborigines and Australia, Allen \& Unwin, St Leonards.

Attwood, B \& SG Foster (eds) 2002, Frontier conflict: the Australian experience, National Museum of Australia, Canberra.

Bickford, A 1981, 'Blacktown: the archaeological investigation of the Native Institution, Blacktown, New South Wales', a report for Lyle Marshall and Associates, Sydney.

Bradley, W 1969, A voyage to New South Wales: the journal of Lieutenant William Bradley RN of HMS Sirius 1786-1792 (reproduced in facsimile from the original manuscript with a portfolio of charts), Trustees of the Public Library of New South Wales in Association with Ure Smith, Sydney. 
Brook, J \& J Kohen 1991, The Parramatta Native Institution and the Black Town: a history, NSW University Press, Kensington, NSW.

Byrne, D 1996, 'Deep nation: Australia's acquisition of an indigenous past', Aboriginal History, 20: 82-107.

Challis, K 2000, Tales from Sydney Cove (edited by Bernard Smith), The Helicon Press, Wahroonga, NSW.

City of Sydney 2002, 'Barani: Indigenous history of Sydney City', available at www.cityofsydney.nsw.gov.au/barani.

Colley, S \& A Bickford 1996, " Real” Aborigines and "real” archaeology: Aboriginal places and Australian historical archaeology', World Archaeological Bulletin 7: 5-21.

Collins, D 1975 [1798], An account of the English colony in New South Wales, vol. 1, A.H. \& A.W. Reed, Sydney.

Collins, D 1975 [1802], An account of the English colony in New South Wales, vol. 2, A.H. \& A.W. Reed, Sydney.

Commonwealth Government, Royal Commission into Aboriginal Deaths in Custody 1991, Regional Report of Inquiry into Underlying Issues in Western Australia of the Royal Commission into Aboriginal Deaths in Custody, Volume 1, [Commissioner P L Dodson], Canberra.

Eidelson, M 1997, The Melbourne Dreaming: a guide to the Aboriginal places of Melbourne, Aboriginal Studies Press, Canberra.

Flynn, M 1995, 'Place of eels: Parramatta and the Aboriginal clans of the Sydney region: 1788-1845', unpublished manuscript, AIATSIS Library.

Goodall, H 1988,'Cryin out for Land Rights' in Burgmann, V \& J Lee (eds) Staining the wattle: a people's history of Australia since 1788, McPee Gribble/Penguin, Fitzroy, Victoria.

Goodall, H 1996, Invasion to embassy: land in Aboriginal politics in New South Wales, 17701972, Allen and Unwin with Black Books, St Leonards.

Hiatt, L 1996, Arguments about Aborigines: Australia and the evolution of social anthropology, Cambridge University Press, Cambridge.

Hinkson, M 2001, Aboriginal Sydney: a guide to important places of the past and present (with photographs by Alana Harris), Aboriginal Studies Press, Canberra.

Horner, J 1994, Bill Ferguson: fighter for Aboriginal freedom, published by the author, Dickson, Canberra.

National Inquiry into the separation of Aboriginal and Torres Strait Islander children from their families (Australia) 1997, Bringing Them Home: Report of the National Inquiry into the separation of Aboriginal and Torres Strait Islander children from their families [Commissioner: Ronald Wilson], Human Rights and Equal Opportunity Commission, Sydney.

Kohen, J, A Knight \& KV Smith 1999, ‘Uninvited guests: an Aboriginal perspective on Government House and Parramatta Park', unpublished report prepared for the National Trust, Sydney.

McBryde, I 1986, 'Australia's once and future archaeology', Archaeology in Oceania, 21, 13-28.

McBryde, I 1989, Guests of the Governor: Aboriginal residents of the First Government House, The Friends of the First Government House Site, Sydney. 
McCarthy, FD (ed) 1970, Aboriginal antiquities in Australia: their nature and preservation, Australian Institute of Aboriginal Studies, Canberra.

McDonald, J 1994, 'Dreamtime superhighway: an analysis of Sydney Basin rock art and prehistoric information exchange', unpublished PhD thesis, the Australian National University, Canberra.

National Trust 2000, 'A different story: an Aboriginal interpretation of Old Government House, Perspectives, February-April: 16-18.

Nugent, M 2002, 'Aboriginality, place and memory in cultural heritage work', paper presented to the History and Memory in Cross-Cultural Research Workshop, Centre for Cross-Cultural Research, The Australian National University, Canberra, 15 October 2002.

Povinelli, E 2002, The cunning of recognition: Indigenous alterities and the making of Australian multiculturalism, Duke University Press, Durham \& London.

Smith, KV 1992, King Bungaree: a Sydney Aborigine meets the Great South Pacific explorers, 1799-1830, Kangaroo Press, Kenthurst, NSW.

-- 2001, Bennelong: the coming in of the Eora, Sydney Cove 1788-1792, Kangaroo Press, East Roseville, NSW.

Stanbury, P \& J Clegg 1996, A field guide to Aboriginal rock engravings with special reference to those around Sydney, Oxford University Press, Melbourne.

Stanner, WEH 1969, After the Dreaming, (The Boyer Lectures 1968), Australian Broadcasting Commission, Sydney.

Stocking, G 1996, After Tylor: British social anthropology 1888-1951, Athlone, London.

Tench, W 1961 [1788; 1793], Sydney's first four years (being a reprint of 'A narrative of the expedition to Botany Bay and A complete account of the settlement at Port Jackson by Captain Watkin Tench'; with an introduction and annotations by L.F. Fitzhardinge), Angus and Robertson in association with the Royal Australian Historical Society, Sydney.

Windschuttle, K 2002, The fabrication of Aboriginal history, Macleay Press, Sydney.

Wolfe, P 1999, Settler colonialism and the transformation of anthropology: the politics and poetics of an ethnographic event, Cassell, London. 